\title{
Australia: historical earthquake studies
}

\author{
Kevin McCue \\ Australian Seismological Centre, Canberra, Australia
}

\begin{abstract}
Historical studies of earthquakes in Australia using information dating back to 1788 have been comprehensive, if not exhaustive. Newspapers have been the main source of historical earthquake studies. A brief review is given here with an introduction to the pre-European aboriginal dreamtime information. Some of the anecdotal information of the last two centuries has been compiled as isoseismal maps. Relationships between isoseismal radii and magnitude have been established using post-instrumental data allowing magnitudes to be assigned to the pre-instrumental data, which can then be incorporated into the national earthquake database. The studies have contributed to hazard analyses for the building codes and stimulated research into microzonation and paleo-seismology.
\end{abstract}

Key words Australia - historical earthquakes

\section{Introduction}

Aboriginal occupants of Australia for the last 60000 years (Horton, 1994) left no written records; history was passed from generation to generation orally as Dreamtime stories, and rock art depicted many of their rituals. Unfortunately there are no dates or times for stories or art that may be interpreted to relate to earthquakes or volcanic eruptions. An example of such a story about the creation of Port Phillip Bay was quoted by McTaggart (1932):

«Aboriginal belief (is) that in the past there was no passage between Points Nepean and Lonsdale, and an earthquake broke the shoreline to make it what it is today».

Another quote is in a personal letter from Fisher to La Trobe (1853) as follows:

«1844 - Geelong district earthquake, native

Mailing address: Dr. Kevin McCue, Australian Geological Survey Organisation, Australian Seismological Centre, Jamison Centre, PO Box 324, ACT 2614, Canberra, Australia; e-mail: asc@netspeed.com.au. informed author that he has felt the same a long time ago».

Aboriginal middens have been discovered buried under volcanic ash, the charcoal enabling age estimates of the eruptions that are described in some of the Dreamtime stories. The youngest eruptions in Western Victoria and southeast South Australia are dated at between 1000 and 5000 years ago (Barbetti and Sheard, 1981).

Portuguese and Dutch seafarers began visiting the Australian continent at least as early as 1606 but the first written record of an earthquake relates to one on Sunday 22 June 1788, felt in Sydney just five months after the first British settlers arrived in southeastern Australia. Subsequent British settlements spread south, north and west from Sydney across the continent in the next 50 years (Hobart Tasmania, 1803; Brisbane Queensland, 1824; Perth Western Australia, 1829; Adelaide South Australia, 1836; and Melbourne Victoria, 1837); and newspapers followed soon after in all cities and most large towns.

Surprisingly for the early European settlers, earthquakes were felt in each of these future state capitals within months of their establishment.

Australia achieved independence from Britain in 1901, becoming a commonwealth of six states and two territories with separate state 
governments and state constitutions. Commonwealth and some state agencies monitor earthquakes in their jurisdictions but arguments about mandated responsibility, and therefore who should pay, have caused network problems over the years.

The first seismograph in Australia, a GrayMilne instrument, was installed at Melbourne in 1888 but records only remain from the second phase of installations when Milne seismographs were established in Perth (1901), Melbourne (1902), Sydney (1906) and Adelaide (1909). Between 1788 and the early 1900s, newspaper articles were the main source of information about earthquakes and continued to be important until the 1960s.

\section{The pre-instrumental period}

Mention of earthquakes in Australia was made in several early texts including the series Historical Records of Australia published by the Library Committee of the Commonwealth Parliament in 1914. These were a reproduction of the original reports of the founding Governor Phillip to Lord Sydney, the Home Secretary in England, which started in 1788. Phillip sent several handwritten versions of the same report on different ships to try to ensure that at least one arrived. The reports were not always identical. A 1789 publication reproduced by the Library of Australian History in 1978 mentions that three earthquakes were felt during the first six months of abode there without further details. One of these would have been the event on 22 June 1788 which is reported to have occurred in the evening in one account by Phillip (Historical Records of Australia, 1914), or at 11:00 a.m. (Howe, 1952). In another account, Phillip does not mention a time of day (Historical Records of Australia, 1914).

The first publication on Australian earthquakes was Jevons's (1859) description of earthquakes in New South Wales between 1788 and 1842. The Reverend W.B. Clarke, known as the father of Australian geology (Mozley, 1965), collected anecdotal information on 160 earthquakes in Australia and New Zealand (Clarke, 1869) but his list of earthquakes was destroyed in a fire in 1882. Heaton (1879) listed a number of earthquakes in most Australian states except Western Australia from 1788 to 1877.

Towards the end of the 19th century, geologists, surveyors, astronomers and meteorologists all took an active interest in earthquakes in Australia and New Zealand and formed the Seismological Committee of the Australasian Association for the Advancement of Science (AAAS). This committee was responsible for the introduction of the Milne pendulum seismometers and for the compilation of lists of reported earthquakes with intensities (Rossi-Forel scale) for the period 1892 to 1913. The committee included A. Biggs, R. Ellery, H. Russell, C. Todd and G. Hogben from both sides of the Tasman Sea. Their lists have been the nucleus for subsequent historical studies of individual events and seismicity studies. Government geologist Edgeworth David prepared a map of earthquakes in SE Australia for publication in the Sydney paper The Daily Telegraph in 1902, reproduced in fig. 1.

Another early scribe (Dodwell, 1910) provided descriptions of earthquakes in South Australia for the four years prior to the installation of the seismograph there, in 1908 according to Dodwell, though other references suggest the Milne was not in operation until 1909. Prior to its shipment to Adelaide this instrument was under test in London at the time of the 1906 San Francisco earthquake and that seismogram was on display at the Science Museum, London until at least the 1970s.

Several seismologists including the author investigated early earthquakes in South Australia but the most significant study was undertaken by Malpas (1993) who produced five volumes of isoseismal maps covering the period 1837 to 1964 , including copies of the source material. Thirty five of the isoseismal maps were drawn for the pre-instrumental period. She also made special studies of the most important events, the larger earthquakes and those near the capital Adelaide.

Burke-Gaffney SJ (1952), whilst based at Riverview College Observatory that was founded in 1909, used the AAAS lists and press reports to compile a list of 82 Australian earthquakes from 1883 up to 1949. A quality indicator was assigned to each location. He apparent- 


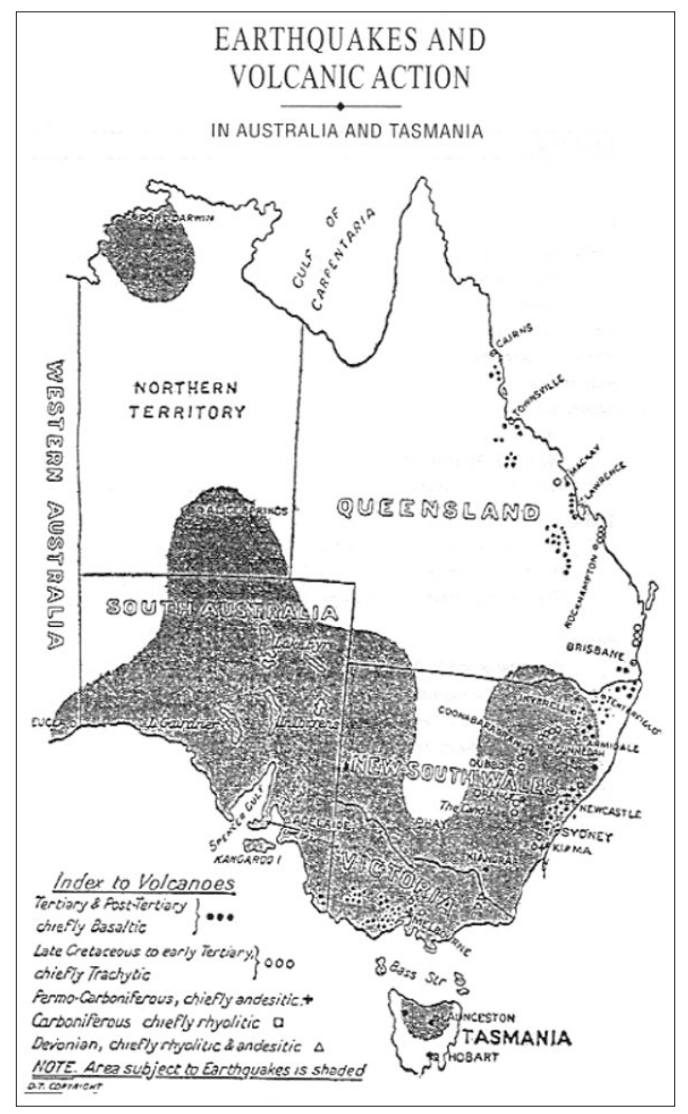

Fig. 1. A 1902 Daily Telegraph newspaper map of earthquakes in Eastern Australia compiled by Edgeworth David.

ly compiled isoseismal maps for the pre-instrumental earthquakes though these have not been found. He did not assign magnitudes to events prior to 1912 in New South Wales, 1922 in Victoria and Tasmania and 1937 in other states.

The Observatory, which houses the longest running seismograph station in Australia, kept a fairly complete newspaper clippings book which provided much useful information for subsequent studies of early earthquakes throughout Australia and in Papua New Guinea.

Doyle et al. (1968) summarised the history of earthquakes and seismological research in Australia up to 1966 and prepared a compre- hensive reference list of historical earthquake sources. They tabulated 161 Australian earthquakes and their lists formed the core of the preliminary computerized Australian earthquake catalogue (Denham et al., 1975).

Everingham and Tilbury (1972) compiled a list of earthquakes in Western Australia from newspapers, meteorological reports and a review of the Perth Observatory seismograms for the period 1849 to 1960 . The same year Underwood (1972) published a catalogue of Victorian earthquakes with intensities, dating back to 1841 .

The first and only historian not also an Earthscientist, to investigate and publish information on historical earthquakes in Australia was Cynthia Hunter. Her self-published book on earthquakes in the Hunter region of New South Wales 1788-1989 (Hunter, 1991) was ready for publication when the 1989 Newcastle earthquake occurred.

A very remarkable sequence of earthquakes occurred northwest of Tasmania in the period 1883 to 1892 (Carey and Newstead, 1960; Ripper, 1963). In the first three years, 2540 earthquakes were felt in NW Tasmania, some of them throughout the island and up to $600 \mathrm{~km}$ away in Kiama New South Wales, $50 \mathrm{~km}$ south of Sydney. These events are shown on Mallet's (1858) map. Michael-Leiba (1989) drew isoseismal maps for the larger Tasmanian earthquakes of the series and the later coincident 1946 event.

Rynn (in Rynn and others, 1987) searched newspapers and other sources to make a comprehensive list of earthquakes in Queensland, and prepared isoseismal maps for the larger earthquakes dating back to 1841 .

\section{Some damaging earthquakes}

Earthquakes are not widely considered a significant threat in Australia but as the historical and recent record demonstrates, earthquake risk is increasing with time as the population expands both numerically and spatially as discussed below. People seem to have a short memory about earthquakes except for those that cause great loss of life or property.

No deaths or significant structural damage were observed in the 19th and late 18th centuries 
in Australia. Since then fifteen deaths resulted from two earthquakes in Australia; in 1902 a magnitude 6.0 earthquake caused two deaths by heart attack in Adelaide, and in 1989 twelve people died in damaged buildings and a thirteenth of a heart attack in Newcastle. The 1989 magnitude 5.6 Newcastle earthquake was the most damaging natural disaster in Australia's modern history to date, causing more than \$A 1.2 billion damage. Most of this damage was to houses, either unreinforced masonry or timber framed houses with unreinforced masonry footings and chimneys. Fourteen schools, two hospitals and the ambulance and fire stations also suffered extensive damage.

The pattern of damage in Newcastle in 1989 mirrored that in the previous most damaging
Australian earthquake, in Adelaide South Australia in 1954. This caused about \$A120M damage, most of it to unreinforced masonry buildings. Instrumental data led the International Seismological Summary (ISS) to locate the epicenter $400 \mathrm{~km}$ south of Adelaide. Bolt (1956), whilst a PhD student of Bullen at Sydney University, studied this earthquake and was able to relocate it close to the Eden-Burnside Fault south of the city where the damage and intensity was greatest. A major hospital and a university now stand at the site of the epicentre.

Most Australian houses have earthquake insurance cover because it is offered free with fire insurance though the deductible amount varies between companies. The problem with insur-

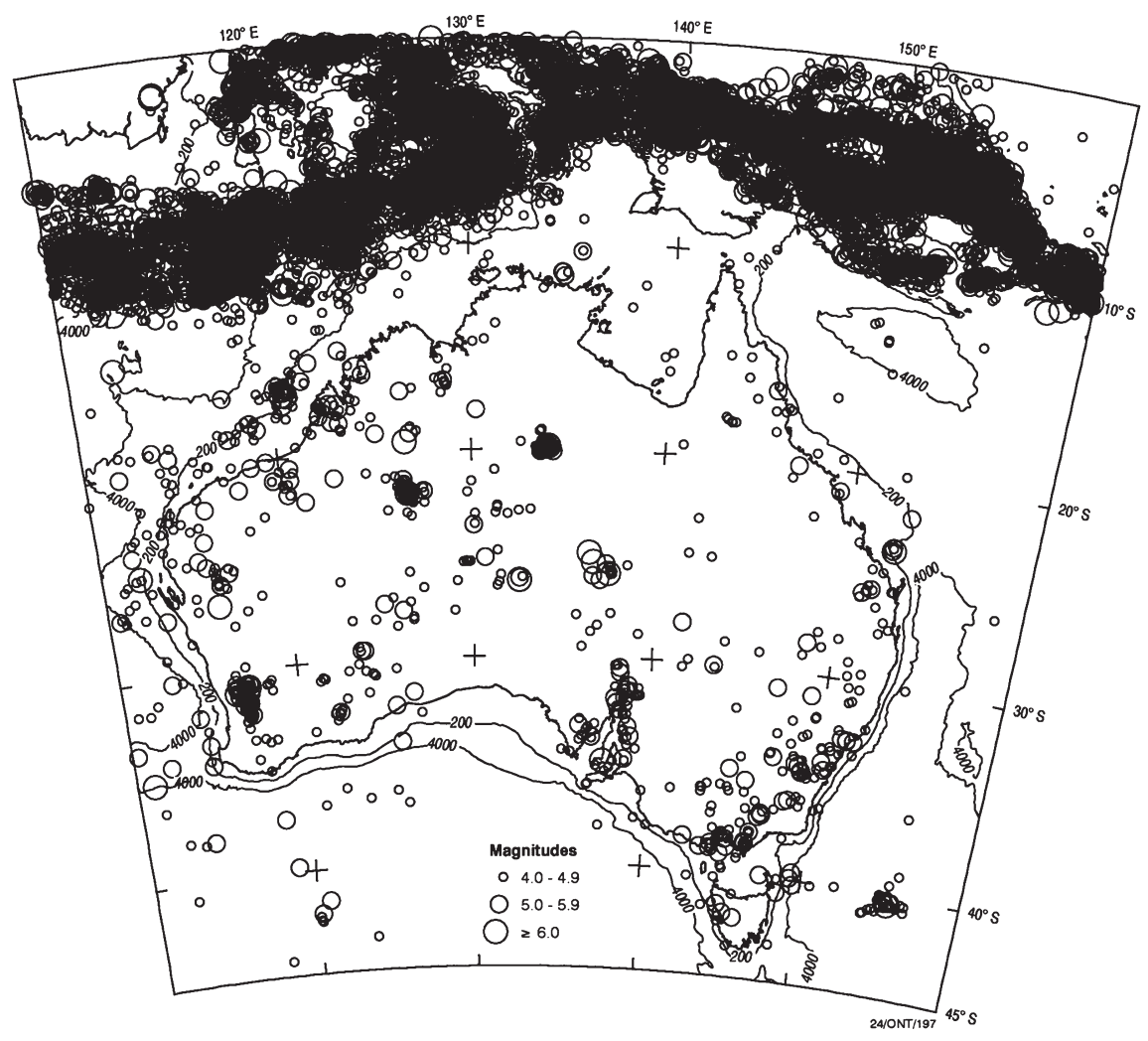

Fig. 2. Seismicity of Australia 1788 to 2000 . The dot size is related to magnitude, the smallest magnitude 4 , the largest magnitude 7.2. 
ance is that it will only cover the cost of restoring the building to its pre-earthquake state, not strengthened or made more resilient to prepare for the next damaging earthquake. A map of known earthquakes of magnitude 4 or more between 1788 and 2000 is shown in fig. 2. The historical events form a subset of the pattern of recent events.

The occurrence of recent large earthquakes, including five of the world's ten known intraplate surface-rupturing events in the 20th century (Johnston and Kanter, 1990), should dispel the notion that earthquake risk is negligible in Australia. The very short instrumental record makes it difficult to be confident when selecting source zones, recurrence rates and maximum magnitudes for either a probabilistic or deterministic seismic hazard analysis, but several attempts have been made making use of the historical data.

The Australian earthquake code is into a third edition since its introduction following the 1968 Meckering earthquake (Bubb, 1999). The goal of the code is life safety but in only a small percentage of Australian buildings have engineers used earthquake engineering principles in their design and construction. Consequently, the next $M 5+$ earthquake near an urban area will cause a repeat of the damage at Adelaide and Newcastle. Nothing will have been learned from history.

The Australian Earthquake Engineering Society (AEES) was established following the 1989 Newcastle earthquake to educate the public and engineers about earthquakes in Australia, to affiliate with the International Association of Earthquake Engineering and to promote links with the New Zealand Society for Earthquake Engineering. It became a Professional Society of the Institution of Engineers Australia and many of its members are on the earthquake loading code committee.

\section{The frequency of earthquakes in Australia}

The Australian continent is wholly intraplate but suffers a relatively high level of seismicity for such an environment. Based on the number and magnitude of recorded events since 1900, the seismicity can be approximately described by a recurrence relation of the form

$$
\log N c=5.3-M
$$

where $N c$ is the cumulative number of earthquakes per year of magnitude $M$ or more (Richter or local scale $\left(M_{L}\right)$ for magnitude 6.0 or less and surface-wave scale $\left(M_{s}\right)$ above magnitude 6.0).

In the last 100 years in Australia the largest known earthquake had a magnitude of $M_{s} 7.2$ and there were about 20 earthquakes that were at least magnitude $M_{s}$ 6.0. From the above equation, the expected once-per-year earthquake has a magnitude (Richter scale) of 5.3, the ten year event magnitude $M$ 6.3. Earthquakes are not randomly distributed across Australia, and nor is the population, most Australians live in cities in a narrow coastal belt in southeastern Australia, so understanding the causes of intraplate earthquakes becomes a critical goal of the hazard computation process.

Compare the Australian record with the earthquake record of the last 100 years in Italy where the largest known earthquake had a magnitude of $M_{s}$ 7.5. There were about seven shallow independent earthquakes of magnitude $M_{s} 6.0$ or more, and the once-per-year (shallow) earthquake has a magnitude of about 5.1. In New Zealand, the rate of shallow seismicity $(\leq 40 \mathrm{~km})$ is also similar to that in Australia.

The land area of Australia is about 25 times that of Italy and 15 times that of New Zealand which accounts for the higher relative hazard rating of Italy and New Zealand.

\section{Australia's current earthquake catalogues}

Only three independent seismic monitoring organisations now exist in Australia and they maintain their own catalogues. They are the Commonwealth Government funded Geoscience Australia (GA), the privately funded Seismology Research Centre (SRC) of Environmental Systems and Services and the State Government operated South Australian Department of Primary Industries and Resources (PIRSA). 


\subsection{History of the catalogues}

Canberra is the hub of a modern telemetered broadband national network operated by GA, some 30 stations, supplemented by networks of triaxial digital mainly triggered recorders operated by SRC in Eastern Australia and PIRSA in South Australia. Altogether there are more than 200 seismographs currently installed in Australia. GA's national network has an average station separation of about $500 \mathrm{~km}$, the SRC and PIRSA networks a station separation of about $50 \mathrm{~km}$. The national detection capability is about $M_{L} 3.2$ whilst SRC and PIRSA claim $M_{L} 1.5$ within their networks.

In the mid-1980s state and university agencies agreed to exchange basic epicentral and arrival time information and to store the epicentre data in a datafile held by the Commonwealth Government's Bureau of Mineral Resources (renamed Australian Geological Survey Organisation and now Geoscience Australia). This datafile was migrated to an Oracle relational database in 1991/92 (Lenz et al., 1992).

Geoscience Australia and SRC operate independent earthquake alarm systems.

\subsection{Description of the National catalogue}

Geoscience Australia's database QUAKES is a world earthquake database built on the ISS, ISC and NOAA historical catalogues. All known solutions are included for each event with a flag marking the preferred solution. A link has been established to the GA tsunami database (McCue and Lenz, 1996) so that the preferred earthquake solution can be linked to observations in the tsunami database. Most of the tsunamis along the Australian coast originated with major earthquakes around the circum-Pacific belt or Banda Sea arc. The largest tsunamis along the southeast coast were from South America in 1868, 1877 and 1960, and along the northwest coast from the 1883 Krakatoa eruption and 1977 Sunda earthquake.

Agencies solicit felt reports for significant or widely felt earthquakes, by questionnaire mailouts, phone and recently by email. There were ten maps compiled each year on average in the 1990s compared with a total of some 70 maps for the historical pre-1900 period.

A table has been set up in QUAKES for intensities which includes the event identification, place name, state, latitude, longitude and intensity with a link to the Australian Place Names Gazetteer to allow selection of the place name and automatic download of the latitude, longitude and state. Isoseismal maps have been drawn up for some 450 earthquakes.

\section{Isoseismal maps}

Many observers and researchers have published isoseismal maps in Australia, using first the Rossi-Forel, then the modified Mercalli scale (Eiby, 1966). Ian Everingham initiated a project to collect all known maps and reproduce them in a standard format and on the modified Mercalli scale. These were subsequently published in three isoseismal atlases (Everingham et al., 1982; Rynn et al., 1987; McCue, 1996). The magnitude range represented by the maps is from $M_{L} 1.6$ to $M_{s} 7.2$ and the period range 1841 to 2000.

Reports of the Australasian Association for the Advancement of Science covering the period 1892 to 1913 provided a valuable reference source for intensities. News articles and letters to the editor in local and regional newspapers were the main source of information. Other useful sources were lighthouse keepers' logs and weather reports compiled by a wide network of meteorological observers. These valuable records have been archived. The occasion of the centenary and then bi-centenary of Australia triggered the publication of a number of regional historical studies that include anecdotal information on important local earthquakes.

With two exceptions historical earthquake reports have all been written in English. The German naturalist Leichhardt happened to be in Newcastle (New South Wales) when the October 1842 earthquake occurred there and his letter to a friend in England (translated by S. Lenz, personal communication) regarding the felt effects was reproduced by McCue (1996). Sieberg (1932), another German naturalist and explorer, published a list of earthquakes in Aus- 
tralia and Papua New Guinea that was translated by G. Hoch (personal communication). The many technical terms in these reports, especially the latter, were a challenge for non-geologist German speakers.

Perrey (1844-1873) too was consulted whilst the author was a student in London but the reports often consisted of «Australian meridian sans details».

\section{Magnitudes from isoseismal maps}

The location of historical earthquakes is usually taken as the centre of maximum damage or the centre of the felt area. Focal depth is difficult to estimate when the reporting population is sparse.

The one missing parameter from all these early catalogues which prevents their use for hazard analyses and addition to databases is the earthquake magnitude. Several attempts have been made to use the Australian intensity information to estimate magnitude as shown in fig. 3. There is a linear relationship between magnitude and felt area, but there may be some unexplained change in the way magnitudes were computed about the mid 1970s.

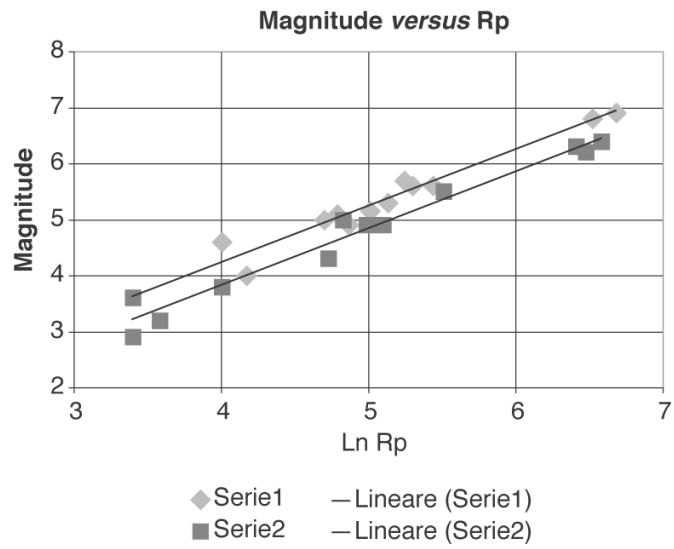

Fig. 3. Plot of magnitude versus Radius of Perceptibility Rp for pre 1977 (diamond) and post 1977 (squares) earthquakes.

\subsection{Radius of perceptibility}

McCue (1980) derived a relationship between magnitude $M$ (Richter scale equivalent) and $\mathrm{Rp}$, the radius of a circle equivalent in area to that enclosed by the MM III isoseismal for Australian earthquakes with measured magnitude ranging from 3.6 to 7.0

$$
M=1.03 \ln R p+0.13 .
$$

This proved to be a simple if approximate method to assign magnitudes for pre-instrumental earthquakes or recent earthquakes that were widely felt but too close or too far from the nearest seismograph to measure the magnitude. The aim of this study was to determine the magnitudes of important historical earthquakes for which isoseismal maps had been drawn.

\subsection{Other intensities}

Greenhalgh et al. (1988) extended this study using ten times more earthquakes in a similar magnitude range to derive relationships between magnitude and $I_{0}, I_{\mathrm{III}}, I_{\mathrm{IV}}$

$$
\begin{gathered}
M_{L}=0.35(0 \pm .12)\left(\log R_{\mathrm{III}}\right)^{2}+0.63( \pm 0.41) \\
\cdot\left(\log R_{\mathrm{III}}\right)+1.87( \pm 0.36) \\
M_{L}=0.38(0 \pm .19)\left(\log R_{\mathrm{IV}}\right)^{2}+0.49( \pm 0.66) \\
\cdot\left(\log R_{\mathrm{IV}}\right)+2.38( \pm 0.57) \\
M_{L}=1.35( \pm 0.34)+0.57( \pm 0.06) I_{0} .
\end{gathered}
$$

Where $I_{0}, R_{\mathrm{III}}, R_{\mathrm{IV}}$ are the epicentral intensity and radius of MM III and MM IV isoseismals respectively. They found that the best estimate of magnitude with the lowest rms deviation was obtained using $R_{\mathrm{III}}$ (equivalent to $R p$ and $I_{\mathrm{III}}$ ).

\subsection{The completeness interval}

It is supposed that in Australia all the $M 6$ or greater earthquakes during the 20th century have been documented, possibly as far back as 1890. The record is not so good for smaller events as indicated in table I. As the networks 
Table I. Magnitude completeness intervals in Australia.

\begin{tabular}{|c|c|c|c|c|}
\hline Magnitude & $\geq 6.0$ & $\geq 5.0$ & $\geq 4.0$ & $\geq 3.0$ \\
\hline Period & 1901- & 1963- & 1975- & 1995- \\
\hline Reason & $\begin{array}{l}\text { First seismic } \\
\text { network and } \\
\text { telegraph line }\end{array}$ & $\begin{array}{l}\text { World-wide } \\
\text { Seismograph } \\
\text { Network }\end{array}$ & $\begin{array}{l}\text { Arrays set up } \\
\text { in Central } \\
\text { Australia }\end{array}$ & $\begin{array}{l}\text { Improved } \\
\text { and expanded } \\
\text { networks }\end{array}$ \\
\hline
\end{tabular}

improved so the detection and location capability improved. The record is better for small areas in the vicinity of local networks established after the International Geophysical Year in southeastern Australia, Tasmania and South Australia in 1957/1958.

\section{The last 20 years}

Records of historical earthquakes are not complete, but it would be surprising if any large earthquakes $M \geq 6$ had been missed since about 1890 when most parts of the continent were populated by Europeans, and a national telegraph network was in place. Unfortunately the historical record can not extend back past 1788 so the resulting catalogue is still a short sample for hazard assessments. This has motivated Australian seismologists to get involved in paleoseismological studies.

Recent more detailed examination of intensity observations has encouraged study of the relationship between intensity and soil foundations, their depth and shear-wave velocity.

\subsection{Microzonation}

Isoseismal maps show that the maximum intensity is not always at the epicentre. This was the case at Newcastle in 1989 where the maximum damage was $15 \mathrm{~km}$ from the epicentre. This observation led to an examination of foundation soils throughout the mesoseismal area and the realisation that shallow sediments correlated closely with damage in one and two storey un-reinforced masonry buildings (Institution of Engineers, 1990).
This in turn led seismologists to undertake a Nakamura-type study of the area and collate all known borehole log records (Somerville and others, 1993). Resonance observed in ground motion spectra generally coincided with the computed quarter wavelength.

\subsection{Paleoseismology}

If the 20th century earthquake history of Australia is typical, and if all Australian earthquakes are shallow, if most large earthquakes have reverse mechanisms and most of them cause surface ruptures then there should be at least 100 Recent fault scarps detectable.

Surface faults in Australia since 1968 show that such scarps are about 30 to $40 \mathrm{~km}$ long and have vertical surface displacements of about $2 \mathrm{~m}$. Such features should be observable which would give us better confidence that the historical record was indeed a representative sample of large earthquakes. A comprehensive paleoseismology study would cast light on the concept of whether a maximum magnitude exists for continental Australia. The current view of seismologists is that $M 7.5$ represents a reasonable upper bound.

Fewer than twelve pre-historic Recent fault scarps have been noted during routine geological mapping (McCue, 1990; 2001). Four of these have been investigated and mapped by paleoseismologists. Satellite photographs of the prominent surface ruptures of the 20th century have been examined but the resolution is still not sufficient to detect such features unless the photo interpreter knew they were there. Air photographs have better resolution but some of the mapped scarps are still difficult to see because of erosion and lack of geographical features. 
Notwithstanding the problems, a systematic search of these airphotos should be made to locate possible scarps followed by ground reconnaissance to map and trench each scarp, to date them and confirm their cause.

\section{Case histories}

\subsection{The 1989 Newcastle earthquake}

A shallow magnitude $M_{L} 5.6$ earthquake struck the regional city of Newcastle New South Wales at 10:27 a.m. on 28 December 1989. Thirteen people were killed and 120 seriously injured, nine died in the partial failure of one building and three pedestrians were crushed under shop awnings which collapsed into the street. At the time, schools and colleges were closed and most workers were on Christmas holidays so injuries and deaths were relatively few.

The first question asked of seismologists by the local council charged with response and recovery was: what is the chance of a damaging aftershock in the next 12 hours? Rescue workers were still trying to find injured people in the partially collapsed building and were at great risk of being killed themselves if a damaging aftershock occurred. The lack of knowledge of past events meant that a considered answer could not be given. Two years later this information was available (Hunter, 1991): past earthquakes of about magnitude 5 near Newcastle in 1837, 1841, 1842, 1868 and 1925 were not followed by aftershocks, at least not large enough to be commented on in contemporary newspapers. These earthquakes ruptured Palaeozoic rock under Mesozoic sediments of the northern Sydney Basin. On the other hand, earthquakes of similar size under the south- ern Sydney Basin in 1961 and 1973 did have extensive aftershock sequences and on that basis the rescuers were ordered from the building until it could be made safe.

\subsection{Tennant Creek Northern Territory}

On 22 January 1988 between local noon and midnight, three large earthquakes shook Tennant Creek in the Northern Territory. The earthquakes were rated $M_{w} 6.3,6.4$ and 6.7 and caused a $35 \mathrm{~km}$ long, $2 \mathrm{~m}$ high fault scarp. Most buildings in the town including the local hospital suffered considerable non-structural damage, but there was remarkably little real damage given that the epicentres and surface scarps of the three events were only $40 \mathrm{~km}$ from the town.

A paleoseismological study of the fault scarps was made in 1992 (Crone et al., 1997). They dug two $25 \mathrm{~m}$ long trenches through the Western Lake Surprise Fault and could not conclusively demonstrate that an ancient fault scarp existed at the first trench site but did find our best evidence of prehistoric surface rupturing in the second trench. Similar short trenches through the Eastern Lake Surprise and Kunayungku scarps showed no evidence of previous faulting. This study led to speculation that large earthquakes in Australia do not recur at the same place, at least not within the last 10000 to 100000 years.

Some engineers have concluded from this that the site of an historic large event may be a safe place to build a high hazard facility. This is not the philosophy of the working group who compiled the current Australian Building Code hazard map.

So what does the historical record tell us? The Australasian Association for the Advancement of Science (AAAS) has provided the fol-

Table II. Earthquake felt reports Northern Territory 27 August 1883, 10 am local time.

\begin{tabular}{ll}
\hline \hline Daly Waters & explosion like blasting and vibration \\
Alice Springs & two distinct explosions \\
Sheep camp (9 miles W of Alice Springs) & ditto \\
Undoolya & ditto \\
\hline
\end{tabular}


lowing few reports (table II) of a previous earthquake in the Northern Territory in 1883. Eminent authors of this report of Committee No. 1 of AAAS assigned intensity RF3 (equivalent to MM3) to the felt reports. Given the time of day this assigned intensity may be on the low side. Daly Waters and Alice Springs are about $800 \mathrm{~km}$ apart and almost equidistant from Tennant Creek. If the epicentre was about midway between them then this felt area would correspond to an earthquake with a magnitude of at least $M_{s} 6.2$ from eq. (7.1). The further the epicentre is east or west of Tennant Creek, the larger the earthquake magnitude would have to have been.

The AAAS authors mention that Daly Waters was struck by an earlier earthquake at about midnight the previous day, sufficiently intense to wake sleepers.

Data are sparse but we conclude that the 1988 large earthquake sequence near Tennant Creek was preceded by one, possibly two large earthquakes 105 years earlier, not 10000 years ago. As noted above, the sequence of large events off $\mathrm{NE}$ Tasmania between 1883 and 1892 was followed by a large event in 1946. Therefore the code committee premise is not unreasonable. We should be wary of accepting the alternative suggestion that sites of large recent earthquakes are relatively safe from future large earthquakes.

\section{Discussion}

The current database of historical and instrumental earthquakes is very sparse despite all the historical studies undertaken to date. That has serious implications for hazard analyses. If Australian earthquakes are randomly distributed across the continent (as argued by some engineers), the hazard at any point is reduced to below the level considered necessary to provide for earthquake-resistant design. Most Australian seismologists do not agree with this hypothesis. In particular, large earthquakes $(M \geq 6)$ in the last 100 years are distributed in the approximate ratio of 3:2:1 from Archaean Western to Proterozoic Central and Mesozoic Eastern Australia.

The Australian population is clustered along the southeast coastline so associated vulnerable structures, infrastructure and lifelines are sparsely distributed. Conversely, oil and gas pipelines, highways and railways are extensive and have high exposure. The most sensitive structures apart from schools and hospitals (which have not been designed to resist earthquakes) are an animal health laboratory near Geelong (note the earthquake reference by aborigines in the introduction) and a new experimental nuclear reactor near Sydney. These two structures have been designed using earthquake engineering principles. A hazardous chemical waste and a radioactive waste material storage facility are planned but final sites have not yet been selected.

Useful information has been gleaned from the historical record on: i) the frequency of large and moderate earthquakes; ii) the spatial extent of possible source zones; iii) the contribution to damage caused by magnification of ground shaking within the foundation soils and; iv) the likelihood of potentially damaging aftershocks in different regions.

The historical information was used in the hazard map of Australia compiled for the current Loading Code and for the Global Seismic Hazard Assessment Program (GSHAP).

Intensity remains the strong motion parameter of choice in Australia because of the lack of accelerographs. A few accelerographs have been installed, two in each city with a population exceeding 50000 residents. Half of the instruments are on rock, the other half on typical foundations for that city. Additional accelerographs are on important structures, mainly large dams. Valuable data has already been recorded on most instruments from small and moderate regional earthquakes and large distant interplate earthquakes.

Earthquakes near $M 8$ in Indonesia shake buildings in Darwin and tall buildings in Perth and Adelaide (more than $2000 \mathrm{~km}$ away), so strongly that buildings have been evacuated. To date no building has suffered observable damage but the number and height of tall buildings is growing rapidly.

To investigate the long-term frequency of large shallow earthquakes and source zone models, and to tackle the uncertainty in estimates of maximum magnitude, a systematic Australia-wide paleoseismological study needs to be undertaken to extend the historical record. 


\section{Acknowledgements}

I would like to thank Sonja Lenz and the two anonymous referees for their valuable comments on the first draft of this paper.

\section{REFERENCES}

Barbetti, M. and M.J. SheARd (1981): Paleomagnetic results from Mounts Gambier and Schank, South Australia, J. Geol. Soc. Aust., 28, 385-394.

Bolt, B. (1956): The epicentre of the Adelaide earthquake of 1954 March 1, J. Proc. R. Soc. NSW, 91, 64-72.

BuBB, C.T.J. (1999): Earthquake engineering in Australia before Meckering and after Newcastle, Bull. N.Z. Nat Soc. Earthquake Eng., 32, 13-20.

Burke-GAFFnEY, T.N. (1952): Seismicity of Australia, $J$. Proc. R. Soc. NSW, 85, 47-52.

Carey, S.W. and G. Newstead (1960): Tasmania University Seismic Net, Publication 84 (Geology Department, University of Tasmania).

Clarke, W.B. (1869): On the causes and phenomena of earthquakes especially in relation to shocks felt in New South Wales and in other provinces of Australia, Trans. R. Soc. NSW, 2, 51-86.

Crone, A.J., M.N. Machette and J.R. Bowman (1997): Episodic nature of earthquake activity in stable continental regions revealed by palaeoseismicity studies of Australian and North American Quaternary faults, Aust. J. Earth Sci., 44 (2), 203-214.

Denham, D., G.R. Small, J.R. Cleary, P.J. Gregson, D.J. SuTTON and R. UNDERWOOD (1975): Australian earthquakes (1897-1972), Search, 6 (1-2), 34-39.

Dodwell, G.F. (1910): South Australian earthquakes, Rep. Aust. Assoc. Adv. Sci., 12, 416-423.

Doyle, H.A., I.B. Everingham and D.J. Sutton (1968): Seismicity of the Australian continent, J. Geol. Soc. Aust., 15 (2), 295-312.

EIBY, G. (1966): The modified Mercalli scale of earthquake intensity and its use in New Zealand. N.Z. J. Geol. Geophys., 9, 122-129.

EveringhaM, I.B. and L. TILBURY (1972): Information on Western Australian earthquakes 1849-1960, R. Soc West. Aust. J., 55 (3), 90-96.

Everingham, I.B., A.J. McEwin and D. Denham (1982): Atlas of isoseismal maps of Australian earthquakes, BMR Bulletin 214.

Greenhalgh, S., D. Denham, R. McDougall and J.M. Rynn (1988): Magnitude-intensity relations for Australian earthquakes, Bull. Seismol. Soc. Am., 78, 374-379.

Heaton, J.H. (1879): Earthquakes, in Australian Dictionary of Dates and Men of our Time (George Robertson, Sydney), p. 89.

Historical ReCORdS OF Australia (1914), The Library Committee of the Commonwealth Parliament, vol. 1, Series 1, p. 50.

HorTON, D. (Editor) (1994): The Encyclopaedia of Aboriginal Australia (Aboriginal Studies Press).

Howe, R. (1952): A Chronology of Momentous Events in Australian History 1788-1828, Part 1 (D.S. Ford).
HunTER, C. (1991): Earthquake Tremors Felt in the Hunter Valley since White Settlement (Hunter House publications, Newcastle, Australia).

INSTITUTION OF ENGINEERS (1990): Report on the Newcastle Earthquake (Institution of Engineers, Australia, IEAust).

Jevons, W.S. (1859): Earthquakes in New South Wales, Mag. Sci. Art, 2, 93-94.

JoHnston, A.C. and L.R. KANTER (1990): Earthquakes in stable continental crust, Sci. Am., 262 (3), 68-75.

Lenz, S., K.F. McCue and G.R. Small (1992): Quakes BMR-ASC World earthquake database, BMR Record 1992/14.

MALLET, R. (1858): Fourth report upon the facts and theory of earthquake phenomena, Report of 28th Meeting of British Association for the Advancement of Science (John Murray, London), 1-136 (plate XI).

McCue, K.F. (1980): Magnitudes of some early earthquakes in South-eastern Australia, Search, 11 (3), 7880 .

McCuE, K.F. (1990): Australia's large earthquakes and Recent fault scarps, J. Struct. Geol., 125 (6), 761-766.

McCuE, K.F. (Compiler) (1996): Atlas of isoseismal maps of Australian earthquakes, Part 3, Record 1996/19 (Australian Geological Survey Organisation).

McCuE, K.F. (Compiler) (2001): Earthquake Epicentres in Australia 1841-2000 and Recent Fault Scarps, 1:10 M Map.

MCCuE, K.F and S. LenZ (1996): The AGSO tsunami database, in «Tsunamis - A Hazard for the SW Pacific and SE Asia», AGU/IEAust Tsunami Workshop, Brisbane 24 July.

McTaggart, E.R. (1932): Port Phillip Basin: an Aboriginal tradition, Victorian Nat., 49 (1), p. 2.

Malpas, K. (1993): Historical Earthquakes in South Australia 1837-1964 (Flinders University, School of Earth Sciences), vols. 1-5 (unpublished).

Michael-LeibA, M.O. (1989): Macroseismic effects, locations and magnitude of some early Tasmanian earthquakes, BMR, J. Aust. Geol. Geophys., 11, 89-99.

MozLEy, A. (1965): The foundations of the Geological Survey of New South Wales, J. Proc. R. Soc. NSW, 98, 91100.

Perrey, A. (1844-1873): Liste de or Note sur les tremblements de terre en ... avec Suppléments, Paris, Dijon, Lyon.

RIPPER, I.D. (1963): Local and regional events recorded by the Tasmania seismic net, Honours Thesis (University of Tasmania, Hobart), (unpublished).

Rynn, J.M.W., D. Denham, S. Greenhalgh, T. Jones, P.J. Gregson, K.F. McCuE and R.S. SMith (1987): Atlas of isoseismal maps of Australian earthquakes, Part 2, BMR, Geol. Geophys., Bulletin 222.

SiEBERG, A. (1932): Die Erdbeben, in Handbuch der Geophysik, edited by B. GUTENBERG (Berlin), vol. IV, 903-915.

Somerville, M., H. Kagami and K. McCue (1993): Seismic amplification determined from microtremor monitoring at alluvial and rock sites in Newcastle, Bull. N.Z. Nat. Soc. Earthquake Eng., 26 (2), 175-184.

UNDERWOOD, R. (1972): Studies of Victorian seismicity, Proc. R. Soc. Victorian, 85, 27-48. 